\title{
CODE SWITCHING AND CODE MIXING IN EFL CLASS AT HOMESCHOOLING KHALIFAH
}

\author{
Hanifah Nabighah Kultsum ${ }^{1}$ \\ Oom Rohmah Syamsudin ${ }^{2}$ \\ English Language and Education Program \\ Universitas Indraprasta PGRI \\ e-mail: hnabighah@gmail.com ${ }^{1}$ \\ e-mail: orsyamsudin@gmail.com ${ }^{2}$
}

\begin{abstract}
This study aims to determine: (1) The type of code-switching and code-mixing used, (2) The function of code-switching and code-mixing used by teachers and students, (3) The reason teachers and students use code-switching and code-mixing. This research was conducted using a qualitative descriptive method. Data collection in this study was carried out by observation, questionnaire, and interview and then analyzed and describing the results. The results show: (1) The types of code-switching and code-mixing often used are the type of intrasentential code-switching is $50.7 \%$. Furthermore, the type of code-mixing alternation is $46.2 \%$. (2) The code-switching and code-mixing functions used by teachers and students are as easy communication as is $42.5 \%$. (3) Teachers and students use code-switching and code-mixing to facilitate communication in class and understand the material presented by the teacher.
\end{abstract}

Keywords: Code Switching, Code Mixing, EFL Class.

\section{Pendahuluan}

Studi code switching dan code mixing tidak dapat dipisahkan dengan sosiolinguistik. Ini dikarenakan code switching dan code mixing adalah bagian dari fenomena sosiolinguistik. Sosiolinguistik adalah dasar kerangka teori untuk mempelajari code switching dan code mixing. Oleh karena itu, sosiolinguistik sangat perlu dijelaskan sebelum kita mempelajari alih kode dan campur kode. Sosiolinguistik adalah ilmu yang mempelajari antara sosiologi dan linguistik. Kata "sosio" yang berati masyarakat dan "linguis" adalah bahasa, jadi sosiolinguistik adalah ilmu yang mempelajari tentang hubungan antara bahasa dan masyarakat.

Holmes dan Wilson (2017: 1) menyatakan bahwa, "sociolinguistics is studying the relationship between language and society" (terjemahan: sosiolinguistik mempelajari hubungan antara bahasa dan masyarakat). Sedangkan Trudgill dalam Jendra (2012:10) menyatakan bahwa, sosiolinguistik merupakan bagian dari ilmu linguistik yang mementingkan bahasa sebagai fenomena sosial dan budaya. Chaer dan Agustina (2010:2) menyatakan bahwa, bidang ilmu antardisiplin yang mempelajari bahasa yang ada kaitannya dengan penggunaan bahasa itu di dalam masyarakat disebut sosiolinguistik. Simatupang (2018:2) menyatakan bahwa, objek kajian sosiolinguistik adalah pilihan bahasa yang ada pada masyarakat aneka bahasa seperti masyarakat yang menguasai dua atau beberapa bahasa yang harus dipilih pada saat berbicara. Variasi bahasa terdapat dalam bahasan sosiolinguistik, Chaer dan Agustina (2010:61) menyatakan bahwa, sosiolinguistik sebagai cabang linguistik yang berusaha menjelaskan ciri-ciri variasi dan menetapkan korelasi ciri-ciri variasi bahasa tersebut dengan ciri-ciri sosial kemasyarakatan. Bahasa memiliki dua aspek fundamental, yaitu bentuk dan makna. Bentuk aspek meliputi suara, tulisan dan struktur. Aspek makna meliputi leksikal, makna fungsional, dan struktural.

Mustakim (dalam buku Rokhman 2013:15) menyatakan bahwa, variasi bahasa atau yang disebut sebagai "ragam dalam konteks ini adalah variasi pemakaian bahasa yang berbeda-beda". Bisa disimpulkan bahwa variasi bahasa bisa terjadi dikarenakan adanya pengguna atau penutur dari bahasa yang berbeda berdasarkan kesepakatan antar pengguna bahasa. Banyak faktor yang mempengaruhi terjadinya variasi 
bahasa berdasarkan ruang lingkup masyarakat seperti budaya, adat istiadat, pendidikan, suku dan beberapa perbedaan lainnya. Dalam sosiolinguistik, penutur menggunakan istilah untuk menampilkan gaya bahasa yang disebut dengan "kode". Orang juga menggunakan kode ketika mereka ingin menekankan penggunaan bahasa atau variasi bahasa dalam komunitas tertentu. Seseorang dapat menggunakan beberapa bahasa dalam sebuah komunikasi untuk mengerti pemahaman orang lain.

Kode adalah varian bahasa yang digunakan masyarakat bahasa tergantung latar belakang penutur dan pendengarnya serta tergantung situasi dan kondisi. Kode bisa berubah-ubah. Ini bisa berupa peralihan kode dan pencampuran kode. Jika ada yang menggunakan Bahasa Indonesia bisa mengubahnya menjadi Bahasa Inggris untuk melanjutkan percakapan atau pembicaraannya, itu disebut alih kode. Misalnya, siswa berkata, "Bahasa Inggris susah dipahami. I don"t understand." Dalam kalimat tersebut, siswa tersebut menggunakan bahasa Indonesia "Bahasa Inggris susah dipahami", kemudian ia menegaskan, "I don"t understand". Siswa menambahkan "I don "t understand" untuk menegaskan itu karena kesulitan pelajaran Bahasa Inggris, siswa tidak mengerti. Siswa menggunakan Bahasa Inggris untuk menegaskan Bahasa Indonesia karena berbagai alasan.

Chaer dan Agustina (2010:110) menyatakan bahwa, "Alih kode sebagai gejala pemakaian bahasa karena berubahnya situasi". Biasanya digunakan ketika kedua penutur berasal dari suku yang berbeda memiliki bahasa yang berbeda. Jendra (2012:74) menyatakan bahwa, peralihan kode adalah penggunaan lebih dari satu bahasa oleh komunikan dalam pelaksanaan suatu tindak tutur. Wardhaugh (dalam Pramono 2018:36) menyatakan bahwa, telah menjelaskan ada dua jenis alih kode, yaitu alih kode situasional dan alih kode metaforis. Alih kode terdapat beberapa jenis atau bentuk, Poplack (dalam Schmidt 2014:24) menyatakan bahwa, mengklasifikasikan tiga jenis peralihan kode utama: alih kode antar-sentensial (intersentential switching), alih kode intra-sentensial (intra-sentential switching), dan alih kode tag (tagswitching).

Dalam komunitas dwibahasa, kita sering menghadapi orang-orang yang mengubah bahasanya, ketika orang mencampurkan satu atau lebih bahasa dalam tindak tutur tanpa ada sesuatu yang memaksa untuk mencampurkan bahasa tersebut. Biasanya ketika orang berbicara tentang alih kode, itu diikuti dengan pencampuran kode. Karena mereka umumnya ada dalam komunitas dwibahasa, persamaan pencampuran kode dan alih kode digunakan dari dua atau lebih bahasa atau variasi dalam tindak tutur. Pencampuran kode adalah fenomena lain yang terkait erat dengan alih kode. Pencampuran kode terjadi tanpa perubahan topik dan dapat melibatkan berbagai tingkat bahasa seperti fonologi, morfologi, struktur tata bahasa, atau item leksikal. Nababan (dalam Aris, 2018:17) menyatakan bahwa, campur kode adalah keadaan berbahasa lain saat orang mencampur dua atau lebih bahasa dalam suatu tindak bahasa atau wacana tanpa ada maksud dalam situasi berbahasa yang menuntut percampuran bahasa itu sendiri.

Siregar (dalam Lubis, 2018:119) menyatakan bahwa, pencampuran kode dibagi menjadi dua jenis, pencampuran intra sentensial dan pencampuran ekstra sentensial. Myusken (dalam Laila, 2017:168) menyatakan bahwa, ada tiga jenis (a) Penyisipan, (b) Bergantian, dan (c) Leksikalisasi Kongruen. Suwito (dalam Irvani, 2019:24) menyatakan campur kode terjadi karena adanya hubungan timbal balik antara peranan (penutur), bentuk bahasa dan fungsi bahasa. Artinya penutur yang mempunyai latar belakang sosial tertentu, cenderung memilih bentuk campur kode tertentu untuk mendukung fungsi-fungsi tertentu. Suwito (dalam Irvani, 2019:24) menyatakan ada dua hal yang paling melatar belakangi peggunaan campur kode, yaitu latar belakang sikap (atitudinal type) atau non kebahasaan dan latar belakang kebahasaan (linguistic type). Bahasa Inggris adalah bahasa asing yang harus di pahami dan dikuasi oleh seluruh masyarakat dunia, tidak terkecuali di Indonesia. Bahasa Inggris adalah salah satu bahasa yang wajib dipahami oleh siswa siswa di Indonesia karena Bahasa Inggris menjadi mata pelajaran utama di Indonesia. Namun karena Bahasa Inggris bukanlah bahasa ibu (B1) di Indonesia tapi menjadi bahasa asing yang pertama yang harus dikuasai.

English Foreign Language (EFL) adalah pembelajaran Bahasa Inggris dimana siswa belajar dan tinggal di negara yang mana Bahasa Inggris bukanlah sebagai bahasa ibu atau bahasa dasar mereka. Dimana di negara tersebut siswa belajar Bahasa Inggris sebagai bahasa asing. Ada tujuan dari kelas English Foreign Language (EFL) di Homeschooling Khalifah ini yaitu meningkatkan kemampuan Bahasa Inggris dalam pemebelajaran Bahasa Inggris. Di era globalisasi seperti sekarang ini buku dan sumber pembelajaran lainnya menggunakan Bahasa Inggris sebagai bahasa dasar dan Bahasa Inggris memiliki pengaruh dalam kehidupan sehari - hari siswa juga di era sekarang ini. Maka dari itu kelas English Foreign Language (EFL) 
INFERENCE: Journal of English Language Teaching

Vol. 4, No. 1, April - July 2021

p-ISSN: 2615-8671

e-ISSN: 2615-868X

ini sangat penting sebagai penunjang meningkatkan kemampuan Bahasa Inggris siswa di Homeschooling Khalifah.

Metode

Dalam melakukan penelitian ini penulis menggunakan pendekatan kualitatif. Sugiyono (2017:910) menyatakan bahwa, metode penelitian kualitatif adalah metode penelitin yang berlandaskan pada filsafat postpositivisme atau enterpretetif, digunakan untuk meneliti kondisi obyek yang alamiah, dimana peneliti adalah instrumen kunci, teknik pengumpulan data dilakukan secara triangulasi (gabungan observasi, wawancara, dokumentasi), data yang diperoleh cenderung kualitatif, analisis data bersifat induktif/kualitatif, dan hasil penelitian bersifat untuk memahami makna, memahami keunikan, mengkonstruksi fenomena, dan menemukan hipotesis.

Peneliti juga menggunakan jenis pendekatan metode penelitian deskripsi dalam penelitian ini. Sugiyono (2017:35) menyatakan bahwa, metode penelitian deskriptif ini dilakukan untuk mengetahui keberadaan variable mandiri, baik hanya pada sat variabel atau lebih (variabel yang berdiri sendiri atau variabel bebas) tanpa membuat perbandingan variabel itu sendiri dan mencari hubungan dengan variabel lain.

Adapun peneliti menggunakan metode penelitian kualitatif deskripsi yaitu agar peneliti dapat mendeskripsikan opini dan pemahan tentang alih kode (Code Switching) pada guru dan siswa kelas English Foreign Language (EFL) di Homeschooling Khalifah. Penelitian dilakukan di Homeschooling Khalifah, Jakarta Timur yang diambil dari satu guru mata pelajaran Bahasa Inggris dan 15 siswa.

Teknik analisis data yang digunakan dalam penelitian ini adalah yang dikemukakan oleh Miles dan Huberman (dalam Sugiyono 2015:246) menyatakan bahwa, analisis data dalam penelitian kualitatif, dilakukan pada saat pengumpulan data berlangsung, dan setelah selesai pengumpulan data dalam periode tertentu. Dari penjelasan tersebut, maka analisis data dalam penelitian kualitatif teridiri dari beberapa komponen, yaitu: (1) pengumpulan data, (2) reduksi data, (3) penyajian data, dan (4) menarik kesimpulan.

\section{Hasil dan Diskusi}

Berdasarkan hasil observasi, bahasa dominan yang digunakan ketika di kelas yaitu bukan Bahasa Inggris. pernyataan ini didukung dengan apa yang dikatakan oleh guru dan siswa di kelas EFL ini, mereka mengatakan bahwa bahasa yang sering digunakan di kelas yaitu Bahasa Indonesia. Selama observasi dalam dua kali pertemuan, guru dan siswa melakukan peralihan bahasa yaitu dari Bahasa Inggris ke Bahasa Indonesia dan sebaliknya yaitu Bahasa Indonesia ke Bahasa Inggris, total dari peralihan tersebut sebanyak 71 kali yang dibagi menjadi tiga bagian jenis Code Switching. Data disajikan dalam tabel 1

Tabel 1. Jenis Alih Kode (Code Switching)

\begin{tabular}{|c|c|c|c|c|c|}
\hline \multirow{2}{*}{ No } & \multirow{2}{*}{ Jenis Alih Kode } & \multicolumn{2}{|c|}{ Jumlah Ucapan } & \multirow{2}{*}{ Total } & \multirow{2}{*}{ Presentase } \\
\cline { 3 - 4 } & Tag Switching & 9 & 11 & 20 & $28.2 \%$ \\
\hline 2 & $\begin{array}{c}\text { Intra-Sentential } \\
\text { Switching }\end{array}$ & 20 & 16 & 36 & $50.7 \%$ \\
\hline 3 & $\begin{array}{c}\text { Inter-Sentential } \\
\text { Switching }\end{array}$ & 7 & 8 & 15 & $21.6 \%$ \\
\hline & TOTAL & $\mathbf{3 6}$ & $\mathbf{3 5}$ & $\mathbf{7 1}$ & $\mathbf{1 0 0}$ \\
\hline
\end{tabular}

Dan peneliti melakukan observasi dalam dua kali pertemuan, guru dan siswa melakukan pencampuran bahasa yaitu dari Bahasa Inggris ke Bahasa Indonesia dan sebaliknya yaitu Bahasa Indonesia ke Bahasa Inggris, total dari pencampuran tersebut sebanyak 26 kali yang dibagi menjadi tiga bagian jenis Code Mixing. Data disajikan dalam tabel 2 
Tabel 2. Jenis Code Mixing

\begin{tabular}{|l|l|l|l|l|l|}
\hline \multirow{2}{*}{ No } & \multirow{2}{*}{$\begin{array}{l}\text { Jenis Code } \\
\text { Mixing }\end{array}$} & \multicolumn{2}{|l|}{$\begin{array}{l}\text { Jumlah } \\
\text { Ucapan }\end{array}$} & \multirow{2}{*}{ Total } & Presentase \\
\cline { 3 - 5 } & & $\mathrm{P} 1$ & $\mathrm{P} 2$ & & \\
\hline 1 & Insertion & 3 & 4 & 7 & $26.9 \%$ \\
\hline 2 & Alternation & 6 & 6 & 12 & $46.2 \%$ \\
\hline 3 & $\begin{array}{l}\text { Congruent } \\
\text { Lexicalization }\end{array}$ & 3 & 4 & 7 & $26.9 \%$ \\
\hline
\end{tabular}

Peneliti melakukan penyebaran kuesioner untuk menjawab permasalahan kedua yaitu fungsi dari code switching dan code mixing. Peneliti melakukan analisis hasil percakapan dalam dua pertemuan. Jumlah peristiwa yang terjadi dari fungsi code switching dan code mixing dalam pembelajaran di kelas EFL yang disajikan dalam Tabel 3.

Tabel 3. Fungsi dari Code Switching dan Code Mixing

\begin{tabular}{|c|c|c|c|c|c|}
\hline \multirow{2}{*}{ No } & \multirow{2}{*}{ Fungsi } & \multicolumn{2}{|c|}{ Jumlah } & \multirow{2}{*}{ Total } & \multirow{2}{*}{ Prosentase } \\
\hline & & P1 & $\mathrm{P} 2$ & & \\
\hline 1 & $\begin{array}{l}\text { Sebagai Penjelasan } \\
\text { makna atau arti. }\end{array}$ & 10 & 11 & 21 & $16.4 \%$ \\
\hline 2 & $\begin{array}{c}\text { Memudahkan } \\
\text { pemahaman inti atau } \\
\text { topik pembelajaran. }\end{array}$ & 14 & 14 & 28 & $21.8 \%$ \\
\hline 3 & $\begin{array}{l}\text { Membangun keakraban } \\
\text { antara guru dan siswa. }\end{array}$ & 8 & 6 & 14 & $10.9 \%$ \\
\hline 4 & $\begin{array}{l}\text { Sebagai kemudahan } \\
\text { dalam berkomunikasi. }\end{array}$ & 33 & 21 & 54 & $42.5 \%$ \\
\hline 5 & $\begin{array}{l}\text { Sebagai pengulangan } \\
\text { pesan. }\end{array}$ & 2 & 1 & 3 & $2.3 \%$ \\
\hline 6 & $\begin{array}{c}\text { Sebagai penghindar } \\
\text { kesalah pahaman }\end{array}$ & 0 & 1 & 1 & $0.7 \%$ \\
\hline 7 & $\begin{array}{c}\text { Sebagai pencari } \\
\text { kesetaraan dalam Bahasa } \\
\text { Inggris }\end{array}$ & 4 & 3 & 7 & $5.5 \%$ \\
\hline & TOTAL & 71 & 57 & 128 & 100 \\
\hline
\end{tabular}

Peneliti juga melakukan wawancara untuk mengetahui permasalahan ketiga yaitu alasan menggunakan code switching dan code mixing pada kelas EFL di Homeschooling Khalifah. Berdasarkan wawancara, guru mengungkapkan bahwa alasan guru menggunakan code switching dan code mixing adalah untuk mengklarifikasi sesuatu yang tidak dipahami oleh siswa ketika guru berbicara bahasa Inggris dan guru Bahasa Inggris melakukan alih kode karena alasan tertentu untuk memudahkan komunikasi antara guru dan siswa. Menurut pendapat guru bisa disimpulkan bahwa alih kode terjadi dikarenakan kurangnya kemampuan Berbahasa Inggris siswa.

Dan berdasarkan hasil wawancara dengan siswa, siswa mengatakan bahwa siswa melakukan alih kode dan campur kode karena memudahkan komunikasi dengan guru Bahasa Inggris di kelas dan membuat mereka lebih memahami materi pembelajaran yang disampaikan oleh guru Bahasa Inggris di kelas pada saat proses pembelajaran berlangsung. Guru Bahasa Inggris juga menyetujui jika menggunakan code switching dan code mixing di kelas EFL selama pembelajaran berlangsung karena alih kode bisa membantu siswa yang memiliki keterbatasan dalam memahami Bahasa Inggris untuk memahami inti dari penyampaian materi pada saat dikelas dan memudahkan komunikasi dengan siswa. 


\section{Simpulan}

Berdasarkan dari hasil dan pembahasan sebelumnya, maka penelitian ini menyimpulkan hasil tujuan masalah, yaitu :

1. Jenis code switching yang digunakan pada kelas EFL di Homeschooling Khalifah. Berdasarkan hasil analisis data jenis code switching yang pertama atau yang sering digunakan di kelas EFL yaitu alih kode intrasentensial (intra-sentential switching) yaitu $50.7 \%$ prosentasenya. Jenis alih kode yang kedua adalah alih kode tag (tag switching) dengan prosentase $28.2 \%$. Dan yang terakhir jenis alih kode yang digunakan di kelas EFL adalah alih kode intersentensial (inter-sentential switching) yaitu $21.6 \%$. Dan jenis code mixing yang digunakan pada kelas EFL di Homeschooling Khalifah. Berdasarkan hasil analisis data jenis code mixing yang pertama atau yang sering digunakan di kelas EFL yaitu alternation yaitu $46.2 \%$. Jenis code mixing kedua ada dua jenis yaitu insertion dan congruent lexicalization karena mendapatkan prosentase yang sama yaitu $26.9 \%$.

2. Fungsi dari code switching dan code mixing yang digunakan guru dan siswa pada kelas EFL di Homeschooling Khalifah. Berdasarkan hasil analisis data pada bab sebelumnya dapat disimpulkan bahwa fungsi dari alih kode dan campur kode yang sering digunakan adalah fungsi alih kode dan campur kode sebagai kemudahan dalam berkomunikasi dengan prosentase $42.5 \%$. Fungsi alih kode dan campur kode yang kedua yaitu memudahkan siswa untuk memahami topik/inti pembelajaran di kelas. Fungsi terakhir yang sering digunakan adalah fungsi sebagai penjelasan makna atau arti yaitu $16.4 \%$.

3. Alasan guru dan siswa menggunakan code switching dan code mixing pada kelas EFL di Homeschooling Khalifah. Menurut analisis hasil data, dapat di simpulkan bahwa alasan guru menggunakan code switching dan code mixing adalah untuk memudahkan komunikasi di kelas dan untuk mengklarifikasi sesuatu yang tidak dipahami oleh siswa ketika menyampaikan pembelajaran di kelas. Dan alasan siswa menggunakan code-switching dan code-mixing di kelas adalah untuk memudahkan komunikasi dengan guru Bahasa Inggris di kelas dan untuk memudahkan memahami pembelajaran yang disampaikan oleh guru Bahasa Inggris pada saat pembelajaran berlangsung.

\section{Daftar Rujukan}

Chaer, A.\& Agustina, L. (2010). Sosiolingustik Perkenalan Awal. Jakarta : Rineka Cipta

Holmes, J., and Nick, W. (2017). An Introduction to Sociolinguistics. (5th Ed.). New York, NY: Routledge.

Jendra, M.I. (2012). SOCIOLINGUISTICS: Study of Societies Languages. Yogyakarta: Graha Ilmu.

Pramono, J., M.G.P, R., Kalangi, L. C. (2018). Penggunaan Alih Kode Instruktur dalam Proses Belajar Mengajar Bahasa Inggris di ELC Education Manado. Kajian Linguistik. 4 (2), 55-67.

Rokhman, F. (2013). Sosiolinguistik: Suatu Pendekatan Pembelajaran Bahasa dalam Masyarakat Multikultural. Yogyakarta: Graha Ilmu.

Safitri, L., Harida, E. S., \& Hamka. (2017). The analysis of code-mixing on students ${ }^{\text {ee }}$ Facebook: A study on the Facebook status and comments of the sixth-semester students TBI IAIN. English Language Teaching and Research, I (1), 164-175.

Schmidt, A. (2014). Between the languages: Code-switching in bilingual communication. Hamburg: Anchor Academic Publishing

Simatupang, R, R., Rohmadi, M., \& Saddhono, K. (2018) Tuturan dalam Pembelajaran Bahasa Indonesia (Kajian Sosiolinguistik Alih Kode dan Campur Kode). Kajian Lingistik dan Sastra, 3 (2), 119130. https://doi.org/10.23917/kls.v3i2.5981

Sitorus, I. (2019). Campur Kode pada Caption Media Sosial Instragram Mahasiswa Sastra China Fakultas Ilmu Budaya Universitas Sumatera Utara. Fakultas Ilmu Budaya, Universitas Sumatra Utara, Medan.

Sugiyono. (2017). Metode Penelitian Kuantitatif, kualitatif dan R\&D. Bandung: Alfabeta 